\title{
A Study on Soil Characteristics in Urban and Rural Areas of Mangalore, Karnataka
}

\begin{abstract}
Tharavathy N.C.
Department of Post-Graduate and Research in Biosciences, Mangalore University Karnataka, India

Abstract: Studies were carried out on some of the physico-chemical characteristics of urban and rural soils of Mangalore, Karnataka. The colour of the rural soil was seen as typical light brown and the colour of the city soil was found to be dark brown. $p H$ values showed slightly alkaline (8.01 \pm 0.07$)$ in rural soil; conductivity was $117.05 \mu \mathrm{S}$ and $185.75 \mu \mathrm{S}$ respectively in urban and rural soil in 1:5 soil suspension. The moisture content recorded was $1.69 \pm 0.07 \%$ and $0.75 \pm 0.001 \%$ and total alkalinity was $0.004 \pm 0.001 \mathrm{mg} / 100 \mathrm{~g}$ and 0.003 $\mathrm{mg} / 100 \mathrm{~g}$ in urban and rural soil respectively. Carbonate content was absent in two samples. Bicarbonate values were found to be almost equal in both the samples $(0.12 \pm 0.08 \%$ and $0.11 \pm 0.08 \%$ in urban and rural soil respectively). Urban soil sample recorded high value $(40.0 \pm 1.63 \mathrm{mg} / 100 \mathrm{~g})$ of chloride than rural soil sample $(7.0 \pm 0.08 \mathrm{mg} / \mathrm{lo0g})$. The values of other parameters in urban and rural soil samples respectively are as follows: organic matter $0.035 \pm 0.01 \%$ and $0.042 \pm 0.01 \%$; nitrate $0.03 \pm 0.01 \mathrm{mg} / 100 \mathrm{~g}$ and $0.05 \pm 0.01 \mathrm{mg} / 100 \mathrm{~g}$; calcium $6.01 \pm 0.24 \mathrm{mg} / 100 \mathrm{~g}$ and $1.68 \pm 0.33 \mathrm{mg} / 100 \mathrm{~g}$; magnesium $3.16 \pm 0.20 \mathrm{mg} / 100 \mathrm{~g}$ and $2.16 \pm 0.33 \mathrm{mg} / 100 \mathrm{~g}$; iron 0.4 $\mathrm{mg} / 100 \mathrm{~g}$ and $0.2 \mathrm{mg} / 100 \mathrm{~g}$; sulphate $7.9 \pm 0.24 \mathrm{mg} / 100 \mathrm{~g}$ and $6.0 \pm 0.24 \mathrm{mg} / 100 \mathrm{~g}$; silicate $20.03 \pm 1.39 \mathrm{mg} / 100 \mathrm{~g}$ and $8.8 \pm 0.9 \mathrm{mg} / 100 \mathrm{~g}$; inorganic phosphate $0.36 \pm 0.41 \mathrm{mg} / 100 \mathrm{~g}$ and $0.05 \pm 0.001 \mathrm{mg} / 100 \mathrm{~g}$.
\end{abstract}

Key words: Soil, pH, sulphate, phosphate, calcium, magnesium, organic matter.

\section{INTRODUCTION}

Soil is one of the important gifts of nature and is a major component of the Earth's ecosystem. It is the mixture of minerals, organic matter, gases, liquids, and the countless organisms that together support life on Earth. Soil particles move from place to place by natural processes like rain and wind, however, a protective cover of grass on the land, trees or other vegetation, slowed down the rate of soil removal by soil erosion ${ }^{[1]}$. Soil is crucial to life and is the basis of agriculture. There is a very complex relationship between soil and other components of the environment. Technology which had seemed to be a boon to the world is a kind of paradox. It provides many of the things which improve the quality of life but in some cases it is responsible for lowering the quality of an environment.

The world's ecosystems are impacted in far-reaching ways by the processes carried out in the soil, from ozone depletion and global warming to rain forest destruction and water pollution. Soil is the largest global carbon reservoir on Earth, and it is potentially one of the most reactive to human disturbance and climate change. As the planet warms, soils will add carbon dioxide to the atmosphere due to its increased biological activity at higher temperatures. Thus, soil carbon losses likely have a large positive feedback response to global warming ${ }^{[2]}$. Soil profile typically includes three horizons$\mathrm{A}, \mathrm{B}$ and $\mathrm{C}$. The living component of the soil is largely confined to the horizon A and B. It is the recipient of enormous quantities of man-made waste products. The two important sources of soil pollution are agricultural sources like fertilizers, pesticides, growth regulating agents, animal wastes and other agricultural practices and non-agricultural sources like disposal of solid and liquid wastes, atmospheric fallouts, insanitary habits, leaching of toxic and harmful substances. The mixture of water and dissolved suspended materials that occupy the soil pore space is called the soil solution. In the present study, soil characteristics in urban and rural area of Mangalore taluk of Dakshina Kannada District, Karnataka were carried out.

\section{MATERIALS AND MethodS}

The soil samples were collected from two sites, one from the rural area (Konaje) of Mangalore where university campus is situated and the other sample from the urban area (Baikampady) of Mangalore city in the month of January, 2012. The two surface soil samples were collected in polythene cover and brought to the laboratory for the analysis of physico-chemical parameters. The parameters 
selected were $\mathrm{pH}$, conductivity, moisture content, total alkalinity, bicarbonates, carbonates, chlorides, organic matter, nitrate, calcium, magnesium, iron, sulphate, silicate, and inorganic phosphate. These parameters were estimated by following the method of Trivedi and Goel ${ }^{[3]}$.

\section{RESUlts AND DiscusSiON}

The variations in $\mathrm{pH}$, conductivity, chloride, calcium, magnesium, sulphate and silicate in urban and rural soil samples are depicted in Fig. 1 and variations in bicarbonates, organic matter, nitrate, iron and phosphate in urban and rural soil sample are presented in Fig. 2.

\subsection{Colour}

The colour of the rural soil was seen as typical light brown which indicates that it is free from pollution. However, the colour of the city soil was found to be dark brown which may be due to the presence of pollutants from vehicles, industries and other man-made activities.

\section{2. $\mathbf{p H}$}

It is a measure of hydrogen ion concentration in soil solution. It strongly affects the availability and solubility of minerals and nutrients, and is regarded as a useful indicator of other soil parameters. Most minerals and nutrients are more soluble in acid soils than in neutral or slightly alkaline soils ${ }^{[4]}$. It was recorded about $6.95 \pm 0.08$ in urban soil and slightly alkaline (8.01 \pm 0.07$)$ in rural soil in 1:5 soil suspensions.

\subsection{Conductivity}

It is a measure of the current carrying capacity and gives a clear idea of the soluble salts present in the soil. The high values of conductivity in rural soil sample show that the level of soluble salts is more in rural soil than the city soil.

\subsection{Moisture content}

It refers to the amount of moisture present in the soil and is expressed as mass of moisture per unit mass of dry soil. In urban soil it was $1.69 \pm 0.07 \%$ and in rural soil it was $0.75 \pm 0.001 \%$.

\subsection{Total alkalinity}

It is the measure of the capacity of the soil to neutralize the strong acid. It determines the type of grasses, shrubs and trees grown in a particular land area. It was less comparatively in rural sample than urban sample. The level of alkalinity in the soil can be increased by adding calcium or magnesium. It was found to be $0.004 \pm 0.001 \mathrm{mg} / 100 \mathrm{~g}$ and $0.003 \mathrm{mg} / 100 \mathrm{~g}$ in urban and rural soil respectively.

\subsection{Carbonates and Bicarbonates}

Carbonate content was not recorded in two samples. Bicarbonate values were found to be almost equal in both the samples.

\subsection{Chlorides}

Chlorine is an important micronutrient as it plays a major role in the functioning of a number of enzyme systems. Most of the chlorides are soluble in water and can be determined directly in soil solution. Urban soil sample recorded high values $(40.0 \pm 1.63 \mathrm{mg} / 100 \mathrm{~g})$ of chloride than rural soil sample $(7.0 \pm 0.08 \mathrm{mg} / 100 \mathrm{~g})$.

\subsection{Organic Matter}

It is a complex mixture of organic substance obtained from the living biomass, dead roots and other plant residues. It was recorded slightly high in the village sample than the urban sample.

\subsection{Nitrate}

It is the anion form of nitrogen; plants can use nitrogen as either the ammonium cation $\left(\mathrm{NH}_{4}^{+}\right)$or the anion nitrate $\left(\mathrm{NO}_{3}{ }^{-}\right)$. It is an important nutrient for the plant. It is recorded slightly low in city soil than the village soil.

\subsection{Calcium}

It is an important macronutrient and helps in the growth of roots and stem of plants. It is soluble in water, so it is found in low concentration ( $1 \%$ by weight) in sandy and heavily leached soil. It is 
supplied to the plant in the form of exchangeable ions and soluble minerals. Calcium is more available on the soil colloids than potassium because calcium minerals are more soluble than potassium bearing minerals (Donahue et al., 1977). It was recorded high in urban soil than rural soil sample.

\subsection{Magnesium}

It is one of the important nutrients required for plant growth and reproduction. It is central to chlorophyll and aids in the uptake of phosphorus. The minimum amount of magnesium required for plant health is not sufficient for the health of forage animals. A common mineral source of magnesium is the black mica mineral, biotite. Magnesium is generally available in soil, but is missing from some regions along the Gulf and Atlantic coasts of the United States due to leaching by heavy precipitation ${ }^{[5]}$. The level of magnesium in two samples recorded was almost equal but the samples were found to be deficient in magnesium, which may be due to the soil erosion and leaching.

\subsection{Iron}

It is one of the most important micronutrient present in the soil. It is present in several peroxidises, catalase and cytochrome oxidase enzymes and also in ferrodoxin, which participates in oxidationreduction reactions of photosynthesis and other metabolic processes. The level of iron was slightly higher in urban soil than rural soil.

\subsection{Sulphate}

The sulphate ion is the form in which plants absorb most of their sulphur from soils. It is essential to the formation of proteins and chlorophyll, and essential to plant vitamin synthesis. Most sulphur is made available to plants, like phosphorus, by its release from decomposing organic matter. If the amount of sulphur is more in soil, when exposed to air and water it produces sulphuric acid due to sulphur oxidation. In the present study, level of sulphate was $7.9 \pm 0.24 \mathrm{mg} / 100 \mathrm{~g}$ and $6.0 \pm 0.24$ $\mathrm{mg} / 100 \mathrm{~g}$ respectively in urban and rural soil samples.

\subsection{Silicate}

A silicate is a compound containing an anionic silicon compound. These are well characterized as solids, but are less commonly observed in solution. Solutions of silicates are usually observed as mixtures of condensed and partially protonated silicate clusters ${ }^{[6]}$. The amount of silicate recorded was $20.03 \pm 1.39 \mathrm{mg} / 100 \mathrm{~g}$ and $8.8 \pm 0.9 \mathrm{mg} / 100 \mathrm{~g}$ respectively in urban and rural soil samples.

\subsection{Inorganic phosphate}

It is an essential macronutrient for plant growth. It is a very important source of fertilizer for the soil but excess of it is toxic to the soil. Soil fertility decline is considered as an important cause for low productivity of many soils ${ }^{[7]}$. This includes nutrient depletion, nutrient mining, acidification, loss of organic matter and increase in toxic elements like Al, Mn ${ }^{[8]}$. (Hartemink, 2006). Most of the phosphorous in soil comes from the mineralisation of organic matter. Lack of phosphorus may interfere with the normal opening of the plant leaf stomata, resulting in plant temperatures 10 percent higher than normal. Phosphorus is most available when soil $\mathrm{pH}$ is 6.5 in mineral soils and 5.5 in organic soils ${ }^{[5]}$. In this study, it was recorded high in city soil compared to the village sample.

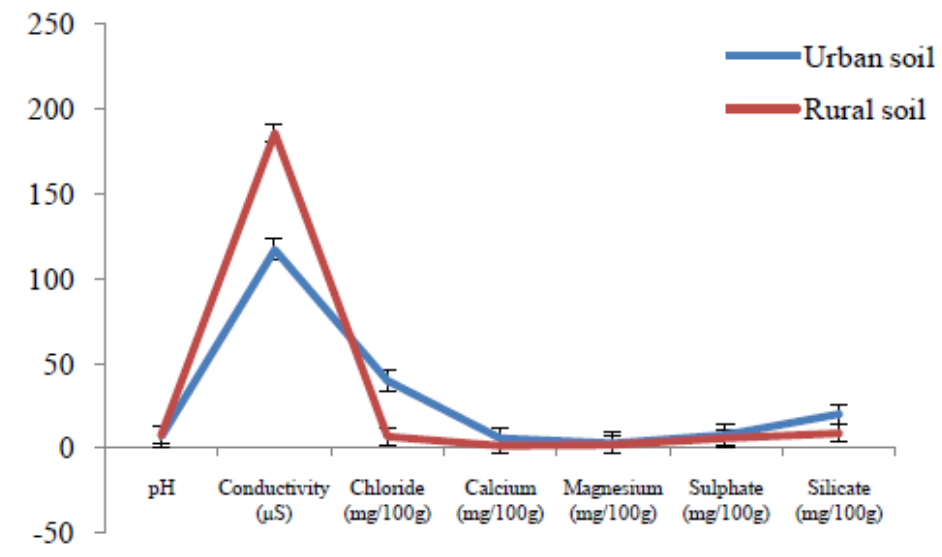

Fig1. Variations in pH, Conductivity, Chloride, Calcium, Magnesium, Sulphate and Silicate in Urban and Rural Soil Samples 


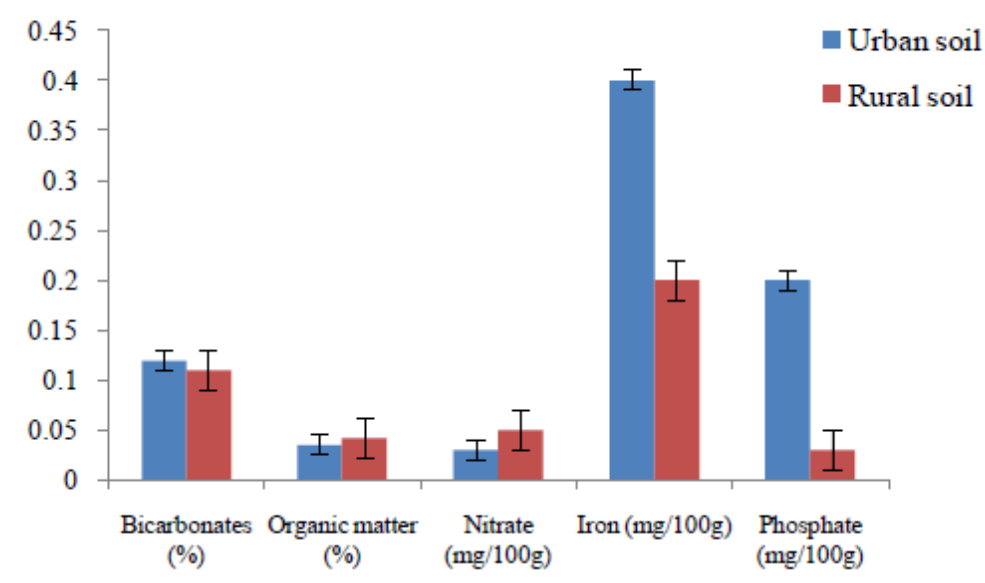

Fig2. Variations in Bicarbonates, Organic Matter, Nitrate, Iron and Phosphate in Urban and Rural Soil Samples

\section{Conclusion}

It is concluded by the study of fourteen physicochemical parameters that urban soil is more chlorinated than rural soil. Results of other parameters showed that urban soil contain higher values of calcium, magnesium, iron, silicate, sulphate and inorganic phosphate, moisture content, total alkalinity and bicarbonates than rural soil whereas other parameters like nitrate, $\mathrm{pH}$, conductivity, organic matter recorded high in rural soil than urban soil.

\section{ACKNOWLEDGEMENT}

The author is thankful to Mangalore University for providing laboratory facilities.

\section{REFERENCES}

[1] Kahalil M., Methane emission from rice paddies need for a downward remission of global estimate. Curr. Sci. 69(25), 293-294 (1995).

[2] Powlson, D., Climatology: Will soil amplify climate change?, Nature, 433, 204-205 (2005).

[3] R.K. Trivedy and P.K. Goel, Chemical and biological methods for water pollution studies, Enviro Media Publications, Karad, India, 1986.

[4] Ololade, I.A, Ajayi, I.R, Gbadamosi, A.E, Mohammed O.Z. and Sunday A.G., A study on effects of soil physico-chemical properties on Cocoa production in Ondo State. Mod. Appl. Sci. 4(5), 35-43 (2010).

[5] R.L. Donahue, R.W. Miller and J.C. Shickluna, Soils: An introduction to soils and plant growth, $4^{\text {th }}$ ed. Prentice Hall, 1977.

[6] C. T. G. Knight, R. J. Bale and S. D. Kinrade, The structure of silicate anions in aqueous alkaline solutions. Angewandte Chemie International Edition 46, 2007, pp 8148-8152.

[7] Sanchez, P.A., Soil fertility and hunger in Africa. Science, 295, 2019-2020 (2002).

[8] A.E. Hartemink, Soil fertility decline: Definitions and Assessment. Encyclopedia of Soil Science, 2006, pp $1618-1621$.

\section{AUTHOR's BIOGRAPHY}

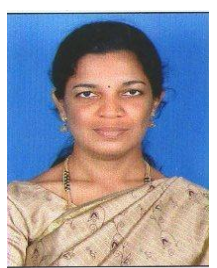

Dr. Tharavathy N.C., obtained her M.Sc., M.Phil. and Ph.D. in Biosciences at the Dept. of Biosciences, Mangalore University. Currently she is working as Associate Professor in the Department of Biosciences, Mangalore University and guiding three Ph.D. scholars in the field of Environmental Science. She has published a book entitled "Metals and pesticides impact on algae and protozoa" in International Publisher LAP LAMBERT Academic Publishing, Germany (ISBN: 978-3-65941234-9). She has presented 16 research papers in National and International Seminars and Conferences and published 20 research articles in different National and International Journals. She has also received "Best Women Scientist Award" from Karnataka Science Congress in the year 2010. She is a Life Member of National Environmental Science Academy, New Delhi and Editorial Board Member of Asian Journal of Environmental Science. 